\title{
Piper betle induces phase I \& II genes through Nrf2/ARE signaling pathway in mouse embryonic fibroblasts derived from wild type and Nrf2 knockout cells
}

\author{
Wan Nuraini Wan Hasan', Mi-Kyoung Kwak², Suzana Makpol', Wan Zurinah Wan Ngah
} and Yasmin Anum Mohd Yusof ${ }^{*}$

\begin{abstract}
Background: Nuclear factor-erythroid 2 p45 related factor 2 (Nrf2) is a primary transcription factor, protecting cells from oxidative stress by regulating a number of antioxidants and phase II detoxifying enzymes. Dietary components such as sulforaphane in broccoli and quercetin in onions have been shown to be inducers of Nrf2. Piper betle (PB) grows well in tropical climate and the leaves are used in a number of traditional remedies for the treatment of stomach ailments and infections among Asians. The aim of this study was to elucidate the effect of Piper betle (PB) leaves extract in Nrf2 signaling pathway by using 2 types of cells; mouse embryonic fibroblasts (MEFs) derived from wild-type (WT) and Nrf2 knockout (NO) mice.

Methods: WT and NO cells were treated with 5 and $10 \mu \mathrm{g} / \mathrm{ml}$ of PB for 10 and $12-\mathrm{h}$ for the determination of nuclear translocation of Nrf2 protein. Luciferase reporter gene activity was performed to evaluate the antioxidant response element (ARE)-induction by PB. Real-time PCR and Western blot were conducted on both WT and NO cells after PB treatment for the determination of antioxidant enzymes [superoxide dismutase (SOD1) and heme-oxygenase (HO-1)], phase I oxidoreductase enzymes [NAD(P)H: quinone oxidoreductase (NQO1)] and phase II detoxifying enzyme [glutathione S-transferase (GST)].

Results: Nuclear translocation of Nrf2 by PB in WT cells was better after $10 \mathrm{~h}$ incubation compared to $12 \mathrm{~h}$. Real time PCR and Western blot analysis showed increased expressions of Nrf2, NQO1 and GSTA1 genes with corresponding increases in glutathione, NQO1 and HO-1 proteins in WT cells. Reporter gene ARE was stimulated by PB as shown by ARE/luciferase assay. Interestingly, PB induced SOD1 gene and protein expressions in NO cells but not in WT cells.

Conclusion: The results of this study confirmed that PB activated Nrf2-ARE signaling pathway which subsequently induced some phase I oxidoreductase, phase II detoxifying and antioxidant genes expression via ARE reporter gene involved in the Nrf2 pathway with the exception of SOD1 which may not be dependent on this pathway.
\end{abstract}

Keywords: Nrf2, PB, ARE, NQO1, HO-1, GST. SOD1

\footnotetext{
* Correspondence: anum@medic.ukm.my

${ }^{1}$ Department of Biochemistry, Faculty of Medicine, Universiti Kebangsaan

Malaysia, Jalan Raja Muda Abdul Aziz, 50300 Kuala Lumpur, Malaysia

Full list of author information is available at the end of the article
} 


\section{Background}

Piper betle L. (PB) from Piperaceae family grows well in South East Asia. The leaves of $\mathrm{PB}$ are used as masticatory in many Asian countries including Malaysia. Eugenol and hydroxychavicol are two bioactive compounds in $\mathrm{PB}$ that have been reported to have antioxidant and anti-inflammatory properties [1,2]. The highest phytochemical present in water extract of $\mathrm{PB}$ leaves is hydroxychavicol which contributed to its antioxidant activity [2]. PB improved antioxidant status by increasing activities of free radical-detoxifying enzymes such as superoxide dismutase, catalase, and glutathione peroxidase during aging in erythrocyte of C57BL/6 mice [3] and increased the levels of nonenzymatic antioxidants such as reduced glutathione in liver and kidney of ethanol-treated rats [4]. Aqueous extract of PB leaves improved antioxidant potential by increasing SOD and catalase activity and also reducing lipid peroxidation in liver and kidney of diabeticinduced Wistar rats [5]. A recent finding showed that PB inhibited proliferation of breast cancer cell lines, MCF-7 and increased antioxidant activities such as SOD1 and CAT [6].

Oxidative stress results from an imbalance between excess production of ROS and limited cellular antioxidant defense [7]. The basic leucine-zipper transcription factor nuclear factor-erythroid 2 p45-related factor 2 (Nrf2) plays a vital role in protecting cells from oxidative stress $[8,9]$. Nrf2 is normally sequestered in the cytoplasm as an inactive complex by interaction with its repressor Keap1 [10]. There are two prevailing models which proposed how Nrf2 is released from Keap1 in response to oxidative stress; (1) the 'hinge and latch' model, in which Keap1 modifications in thiol residues of Keap1 disrupt the interaction with Nrf2 causing misalignment of the lysine residues within Nrf2 that can no longer be polyubiquitinylated, and (2) the model in which thiol modification causes dissociation of Cul3 from Keap1 [11]. In both models, the inducer-modified and Nrf2-bound Keap1 is inactivated and, consequently, newly synthesized Nrf2 proteins bypass Keap1 and translocate into nucleus, bind to the Antioxidant Response Element (ARE) and leads to transcriptional induction of Nrf2 target genes such as heme oxygenase-1 (HO-1), superoxide dismutase (SOD1), catalase (CAT), $\mathrm{NAD}(\mathrm{P}) \mathrm{H}$ quinone oxidoreductase (NQO1), glutathione S-transferase (GST), and including glutathione biosynthesis enzymes glutathione cysteine ligase modifier subunit (GCLM) and glutathione cysteine ligase catalytic subunit (GCLC) [11-18].

Some phytochemical compounds that have been reported to activate the Nrf2/ARE pathway include sulforaphane from broccoli $[19,20]$, quercetin from onions [21] and epigallocatechin-3-gallate from green tea [20]. To our knowledge no information is available on the association of $\mathrm{PB}$ with the Nrf2/ARE signalling pathway.
The aim of this experiment was to evaluate whether $\mathrm{PB}$ can modulate Nrf2/ARE pathway with subsequent increase in phase 2 and endogenous antioxidant enzymes using mouse embryonic fibroblast (MEF) from wild-type and Nrf2 knockout mice.

\section{Methods \\ Materials}

Mouse embryonic fibroblasts (MEFs) were a kind gift from Kwak Mi-kyoung (The Catholic University of Korea, Bucheon, South Korea) and Nobunao Wakabayashi (University of Pittsburgh, USA).who have prepared the cell line from wild type $\left(\mathrm{Nrf2}^{+/+}\right)$and $n r f 2$-disrupted $\left(\mathrm{Nrf2}^{-1-}\right)$ ICR mice [22]. Reporter plasmid containing NQO1 ARE-luciferase [23] was also a kind gift from Kwak Mi-kyoung.

\section{Cell culture}

MEFs cells were cultured in Iscove's modified Dulbecco's medium (Invitrogen, USA) supplemented with 10\% FBS (PAA, USA), 10 unit/ml penicillin-streptomycin and $2.5 \mu \mathrm{g}$ amphoterecin-B (PAA, USA).

\section{MTS assay}

Cells were plated at a density of $5 \times 10^{3}$ cells/well in 96well plates. After $24 \mathrm{~h}$ of incubation the cells were treated with various concentrations of aqueous $\mathrm{PB}$ extract. Then, $20 \mu \mathrm{l}$ MTS solution (Promega, USA) was added to each well and the cells were further incubated for $4 \mathrm{~h}$. The absorbance was measured at $490 \mathrm{~nm}$ using a Versamax microplate reader (Sunnyvale, CA, USA).

\section{Aqueous extraction of Piper betle leaves}

Dried PB leaves were purchased from Ethno Resources Company (Sungai Buloh, Selangor, Malaysia) and confirmation of identification of the plant was obtained from Herbarium, Universiti Kebangsaan Malaysia, Bangi with voucher number UKMB 29768. Aqueous extraction of PB was prepared according to Pin et al. [2] with some modifications. Briefly, the leaves were ground into powder and concentration of $10 \%$ PB was prepared and the extraction process was done using a Soxhlet Extractor (Eyela, Japan). The PB aqueous extract was freeze dried (Labconco, USA). into powder form and stored at $4^{\circ} \mathrm{C}$ until further use.

\section{Reporter plasmid transfection and luciferase activity measurement}

Cells were transfected with plasmids at 50\% confluence using Welfect-Ex Plus transfection reagent (WelGene, Daegu, South Korea). Briefly, cells were incubated with the transfection complex containing $0.5 \mu \mathrm{g}$ ARE-luciferase plasmid, $0.05 \mu \mathrm{g}$ pRLtk control plasmid, and the transfection reagent $(2 \mu \mathrm{g}$ Welfect-Ex and $1.5 \mu \mathrm{g}$ Enhancer-Q) in 
serum-and antibiotic-free OptiMEM (Invitrogen, USA). Transfection was continued for $18 \mathrm{~h}$; the cells were then recovered in complete medium for the next $8 \mathrm{~h}$. The cells were treated with 5 and $10 \mu \mathrm{g} / \mathrm{ml}$ of PB for $24 \mathrm{~h}$ and were then lysed with lysis buffer [RIPA buffer (Sigma, USA) and protease inhibitor cocktail tablet (Roche, Switzerland)]. Luciferase activities from firefly and Renilla luciferases in total cell lysates were determined using a Dual-Luciferase Assay kit (Promega, Wisconsin, USA) with a 20/20n luminometer (Turner Biosystems, Sunnyvale, CA, USA). Wild-type cells were treated with $5 \mu \mathrm{M}$ sulforaphane (SFN) for $6 \mathrm{~h}$ as a positive control.

\section{Preparation of nuclear extracts}

For Nrf2 detection in the nucleus, cells were grown with a density of $6 \times 10^{5}$ and were treated with 5 and $10 \mu \mathrm{g} / \mathrm{ml}$ of PB for 10 and $12 \mathrm{~h}$. After treatment, the cells were washed with cold-PBS. Crude nuclear fractions were obtained by lysing cells in homogenization buffer $[2 \mathrm{M}$ sucrose, $1 \mathrm{M}$ Hepes, $2 \mathrm{M} \mathrm{MgCl}_{2}$, $2 \mathrm{M} \mathrm{KCl}, 30 \%$ glycerol, 0.5 M EDTA, 1 M dithiothreitol, protease inhibitor cocktail (Sigma, USA), and 0.2\% NP-40 (Sigma, USA)], scraped off, vortexed for $30 \mathrm{~min}$ at $4^{\circ} \mathrm{C}$ and followed by centrifugation at $12,000 \times \mathrm{g}$ for $15 \mathrm{~min}$. Protein concentration was determined using Bio-Rad protein assay dye (Hercules, CA).

\section{RNA extraction and quantitative real-time PCR}

Cells were seeded in 6-well plates at $2 \times 10^{5} /$ well and cultured for 24-h. After 24-h treatment with 5 and $10 \mu \mathrm{g} / \mathrm{ml}$ of PB extract, the cells were washed with PBS and RNA was isolated using TRI reagent (Molecular Research Centre, Inc., USA). PCR amplification was performed with a thermal cycler (BioRad, USA). The mRNA level was quantified by Bio-Rad iCycler and the condition for PCR amplification was 40 cycles of $10 \mathrm{sec}$ at $95^{\circ} \mathrm{C}$ for denaturation and $30 \mathrm{sec}$ at $56^{\circ} \mathrm{C}$ for annealing. The primers sequences for the genes are listed in Table 1 and were synthesized by FirstBase (Singapore).

\section{Western blot analysis}

Cells were incubated with 5 and $10 \mu \mathrm{g} / \mathrm{ml}$ of PB for $24 \mathrm{~h}$ for detection of NQO1, HO-1 and SOD1 protein expression. Briefly, $2 \times 10^{4}$ of cells were cultured in $60 \mathrm{~mm}$ petri dish and after $24 \mathrm{~h}$ treatment, the cells were lysed by using lysis buffer [RIPA buffer (Sigma, USA) and protease inhibitor cocktail tablet (Roche, Switzerland)] to extract the protein from cytosol. Finally, the cell lysates were centrifuged at 16,100 $\times \mathrm{g}$ for $30 \mathrm{~min}$ and supernatant was stored at $-80^{\circ} \mathrm{C}$. Both cell lysates from cytosolic and nuclear extract were loaded on 12 or $15 \%$ SDS-polyacrylamide gels and separated by electrophoresis at $70 \mathrm{~V}$ using Mini-PROTEAN 3 cell system (BioRad, USA). Proteins on gels were transferred to PVDF membranes (Amersham
Table 1 Oligonucleotide sequences for real-time PCR of murine phase 2 and antioxidative enzymes

\begin{tabular}{lllc}
\hline Gene & & Sequences $\left(\mathbf{5}^{\prime}\right.$-' $\mathbf{3}^{\prime}$ ) & Accession No \\
\hline 3-actin & Forward & GAAGAGCTATGAGCTGCCTGA & NM_007393.3 \\
& Reverse & GCACTGTGTTGGATAGAGGT & \\
Nrf2 & Forward & GAACTGTAGGAAAGGAAGC & U20532 \\
& Reverse & GAGTATTCACTGGGAGAGTA & \\
NQ01 & Forward & TTCTCTGGCCGATTCAGAGT & X13356 \\
& Reverse & GGCTGCTTGGAGCAAAATAG & \\
SOD1 & Forward & CGGATGAAGAGAGGCATGTT & Z18857 \\
& Reverse & CACCTTGCCCAAGTCATCT & \\
GSTA1 & Forward & CCGTACTTGCCTGCCTTG & NM_145740 \\
& Reverse & CTTCTTCACATTGGGGGGCT & \\
\hline
\end{tabular}

Biosciences, UK) and the membranes were blocked with $5 \%$ skim milk in TPBS buffer $(8 \mathrm{~g} / \mathrm{L} \mathrm{NaCl}, 0.2 \mathrm{~g} / \mathrm{L} \mathrm{KCl}$, $1.44 \mathrm{~g} / \mathrm{L} \mathrm{Na} 2 \mathrm{HPO}_{4}, 0.24 \mathrm{~g} / \mathrm{L} \mathrm{KH}_{2} \mathrm{PO}_{4}$, and $2 \mathrm{ml} / \mathrm{L}$ Tween 20) for $1 \mathrm{~h}$. Antibodies against $\beta$-actin, lamin B, SOD1 and NQO1 were purchased from Santa Cruz Biotechnology (Santa Cruz, CA, USA) while antibodies against HO-1 and HO-1 were purchased from Abcam, (Cambridge, UK). Primary antibody incubation was performed overnight followed by incubation with secondary antibody conjugated to horseradish peroxidase (SantaCruz, USA) for $1 \mathrm{~h}$. Detection of proteins was performed using the Enhanced Chemiluminescence reagent (Amersham Biosciences, UK).

\section{Statistical analysis}

Statistical analysis was conducted using the SPSS software for Windows, version 16.0. Differences between mean values of multiple groups were analyzed by oneway analysis of variance (ANOVA) with Tukey's HSD post-hoc test. Confidence level at the $95 \%(P<0.05)$ was considered statistically significant.

\section{Results}

Viability of WT and NO cells to PB treatment

MTS assay was performed to measure cell viability after $24 \mathrm{~h}$ treatment with increasing doses of PB. N0 cells displayed almost 2-fold increased sensitivity $\left(\mathrm{IC}_{50}\right)$ to $\mathrm{PB}$ compared to WT cells (Figure 1). This result indicated that N0 cells are more susceptible to cytotoxicity of PB treatment compared to WT cells.

\section{Translocation of Nrf2 to nucleus by PB}

To verify dissociation of Nrf2 from Keap1, we measured the translocation of Nrf2 protein into the nucleus in both WT and N0 cells after 10 and $12 \mathrm{~h}$ treatment with PB. After $10 \mathrm{~h}$ of $10 \mu \mathrm{g} / \mathrm{ml}$ PB treatment, nuclear Nrf2 level in WT cells was significantly different $(\mathrm{p}<0.05)$ compared to N0 cells while treatment for $12 \mathrm{~h}$ resulted in no significant changes of Nrf2 proteins between the 


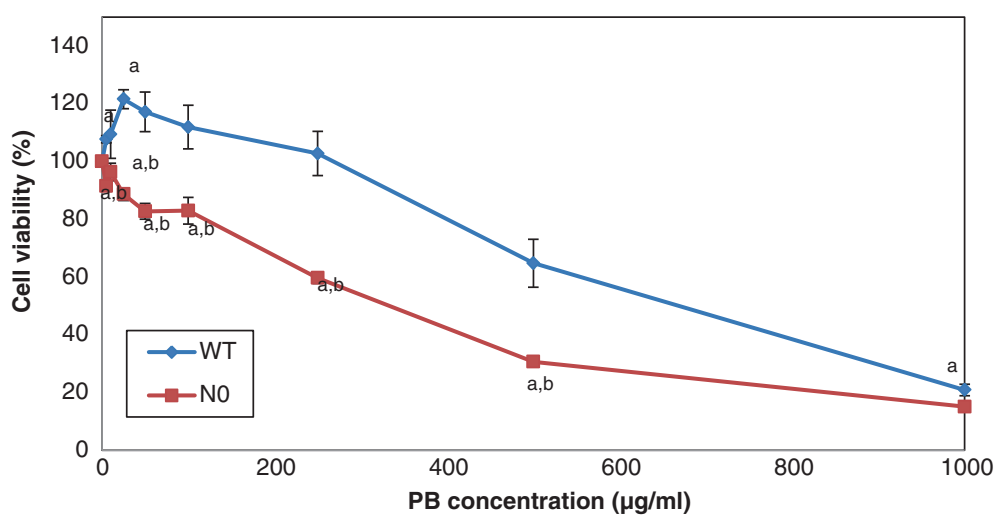

Figure 1 NO cells display increased toxicity to PB aqueous extract. WT and NO cells were treated with increasing doses of PB for 24 h and cell viability was assessed by the MTS assay. Mean cell viability are expressed as percentage of control. Data represent \pm S.E.M from three independent experiments. ${ }^{a} P<0.05$, compared to control; ${ }^{b} P<0.05$, compared to WT cells at the same concentration.

two types of cells (Figure 2). When compared to with the positive control of $5 \mu \mathrm{M}$ sulforaphane on WT for $6 \mathrm{~h}, \mathrm{~PB}$ treatment for $10 \mathrm{~h}$ activated Nrf2 and translocated it into the nucleus at a lower level compared to SFN. This suggested that PB activated Nrf2 protein which subsequently translocated from the cytosol to the nucleus better after $10 \mathrm{~h}$ treatment when compared to $12 \mathrm{~h}$ treatment.

\section{ARE-luciferase reporter gene activity}

The inducer effect of $\mathrm{PB}$ on antioxidant and phase 2 genes mediated via ARE was verified as shown in Figure 3. Both WT and N0 cells were transfected with luciferase reporter plasmid containing the NQO1-ARE. Treatment of WT cells transfected with NQO1-ARE at $10 \mu \mathrm{g} / \mathrm{ml}$ of PB for 24-h showed 1.6-fold increase in luciferase activity compared to control (Figure 3).

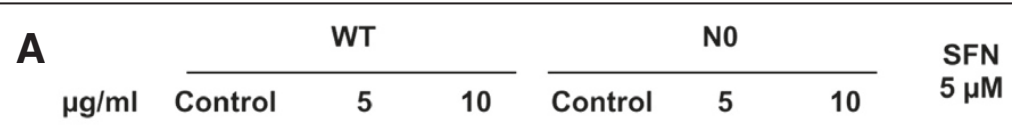

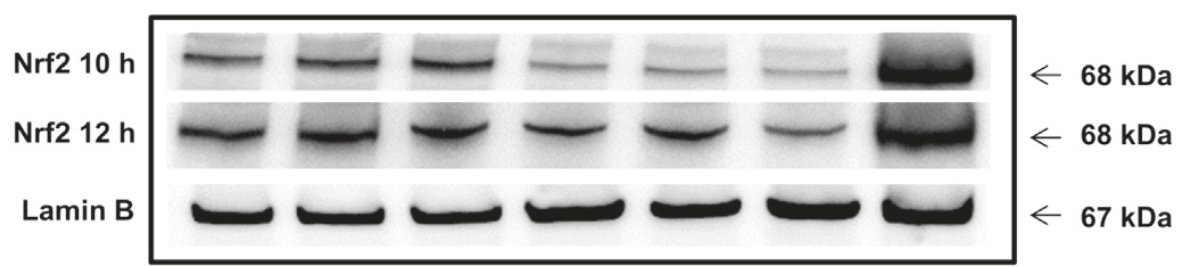

B

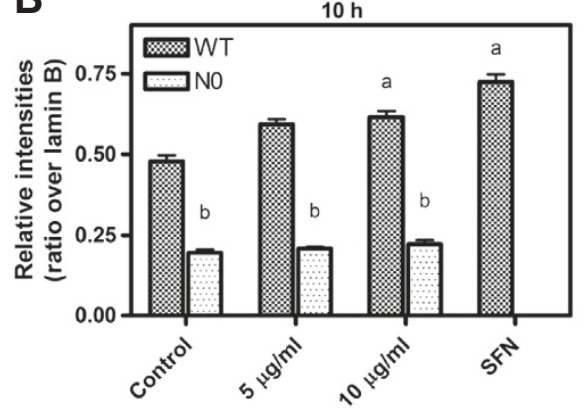

C

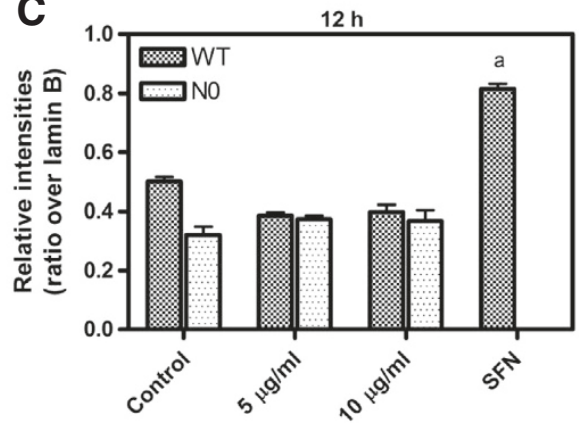

Figure 2 Western blot analysis of nuclear translocation of Nrf2 by PB in Mouse Embryonic Fibroblast (MEF) of wild type (WT) and Nrf2 knockout cells (N0) for 10 and $\mathbf{1 2} \mathrm{h}$ treatment. The blots shown are examples of three separate experiments (A) of Nrf2 protein in the nucleus after 10 and $12 \mathrm{~h}$. SFN treatment for $6 \mathrm{~h}$ serve as the positive control for Nrf2 activation and translocation into the nucleus. MEF cells were treated with PB (5 and $10 \mathrm{\mu g} / \mathrm{ml}$ ) for (B) $10 \mathrm{~h}$ (C) $12 \mathrm{~h}$, after which the cells were gathered and Nrf2 protein was extracted from the nucleus. Lamin B was used as internal control. Data represent \pm S.E.M from three independent experiments. ${ }^{a} P<0.05$, compared to control WT cells; ${ }^{b} P<0.05$, compared to respective WT cells group. 


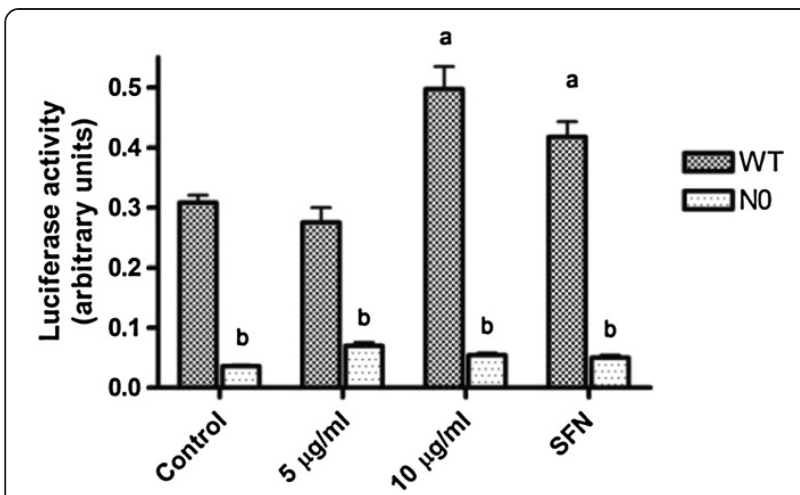

Figure 3 ARE-driven luciferase activities after treatment with PB in MEFs WT and NO cells. The cells were transfected with the luciferase reporter plasmid containing the NQO1 ARE and were treated with PB (5 and $10 \mu \mathrm{g} / \mathrm{ml})$ or SFN $(5 \mu \mathrm{M})$ for $24 \mathrm{~h}$. Measurement of luciferase activities was performed using the Dual luciferase activities and Firefly luciferase levels were normalized to Renilla luciferase levels. Data represent \pm S.E.M from four independent experiments. ${ }^{a} P<0.05$, compared to control WT cells; ${ }^{b} P<0.05$, compared to respective WT cells group.

Effects of PB on gene expressions of antioxidants, phase I and phase II detoxifying enzymes

To explore the effect of PB on Nrf2-genes, WT and N0 cells were treated with $\mathrm{PB}$ and transcript levels for $\mathrm{Nrf} 2$, NQO1, SOD and GSTA1 genes were assayed via real time PCR. At the baseline, Nrf2, NQO1 and GSTA1 genes were highly expressed in WT cells compared to N0 cells (Figure 4). Treatment with PB at $10 \mu \mathrm{g} / \mathrm{ml}$ for 24-h for both type of cells significantly increased Nrf2, NQO1 and GSTA1 genes expression in WT, but not in N0 cells. SOD1 gene expression was significantly greater in N0 cells compared to WT cells at the baseline. However, when the cells were treated with $\mathrm{PB}$, there was no significant difference in SOD1 expression between WT and NO cells.

\section{Effects of PB on NQO1 and HO1 protein expressions}

To verify the induction of $\mathrm{PB}$ on Nrf2-regulated proteins, we measured the expression of NQO1 and HO-1 proteins by Western blot technique. At the basal level, NQO1 and HO-1 proteins were significantly expressed in WT cells compared to N0 cells (Figure 5A). When the cells were treated with $10 \mu \mathrm{g} / \mathrm{ml}$ PB for $24-\mathrm{h}$, NQO1 and $\mathrm{HO}-1$ proteins were significantly increased in WT cells, but not in N0 cells. SOD1 protein however, was significantly expressed in N0 cells (Figure 5D) in accordance with the expression of SOD1 genes (Figure 4C) with PB treatment. However there was no significant difference in SOD1 expression between WT and N0 cells.

\section{Discussion}

The underlying mechanism by which local plant Piper betle (PB) stimulates Nrf2 pathway has yet not been elucidated. Our results on NQO1-ARE luciferase activity, mRNA, phase I oxidoreductase and phase II detoxifying enzymes showed that PB induced Nrf2/ARE pathway.

This study illustrated that Nrf2 deficiency in MEF cells (N0) resulted in increased cytotoxicity with PB treatment compared to WT cells. Hydroxychavicol which is found in $\mathrm{PB}$ was shown to exert antioxidant activity at low concentration but display pro-oxidant effect at concentration higher than $0.1 \mathrm{mM}$ [24]. Similarly, $\mathrm{Nrf2}^{-/-} \mathrm{MEF}$ cells were shown to be more sensitive to SFN treatment, peroxides, anti-cancer drugs (Displatin) and compounds that generate free radical compared to $\mathrm{Nrf}^{+/+}$ MEF cells [25].

The Nrf2-Keap1-ARE signaling system is central to the induction of phase 2 genes by electrophiles and antioxidants $[16,17,20,21]$. We showed that PB was able to activate Nrf2 and translocated into the nucleus, with increased expression of NQO1 and $\mathrm{HO}-1$ genes and proteins. We postulate that the mechanism of interaction between PB and Nrf2-Keap1 complex may mimic the action of other Nrf2 inducers such as sulforaphane and Gingko biloba extract. Keap1 protein contains multiple cysteine residues and specifically C257, C273, C297 and C288 were shown to be the most reactive residues that can interact with phase 2 inducers including sulforaphane [10]. Upon exposure to inducers, the reactive cysteine residues form intermolecular disulfide bonds and change its conformation which leads to dissociation of Nrf2 from Keap1, translocating Nrf2 into the nucleus, and activating the expression of phase 2 genes [26]. Ginkgo biloba extract stimulated Nrf2, and translocated it into the nucleus with subsequent increase in phase 2 genes such as GCLC, GST and NQO1 through Keap1-Nrf2-ARE signaling pathway in Hepa1c1c7 and HepG2 cells [27]. The active compound in coffee, 5-O-caffeoylquinic acid (CGA) modulates Nrf2 nuclear translocation and ARE-dependent gene expression such as HO-1, Nrf2, GST, үGCL in HT29 cells [28].

In this study, we showed that Nrf2 translocation is better at $10 \mathrm{~h}$ incubation of $\mathrm{PB}$, and for ARE induction, genes and proteins expression, we incubated the cells with $\mathrm{PB}$ for $24 \mathrm{~h}$, which is similar to other studies [27,29]. Sulforaphane caused nuclear translocation of Nrf2 after $6 \mathrm{~h}$ treatment by Western blotting; however immunocytochemistry data revealed that translocation of Nrf2 in the nucleus was not seen in many cells at $6 \mathrm{~h}$ treatment compared to $24 \mathrm{~h}$ incubation that displayed high amount of Nrf2 in the nucleus of human keratinocytes cells [29].

The antioxidant response elements (ARE) are a cis-acting enhancer sequence located in the 5'-flaking promoter region of antioxidant and detoxifying genes such as GST, HO-1, GCLC and NQO1 [30-35]. The luciferase reporter assay further confirmed that $\mathrm{PB}$ induced ARE promoter region in the nucleus. Our results are supported by Shin et al. [16] who reported that sulforaphane, a well known 

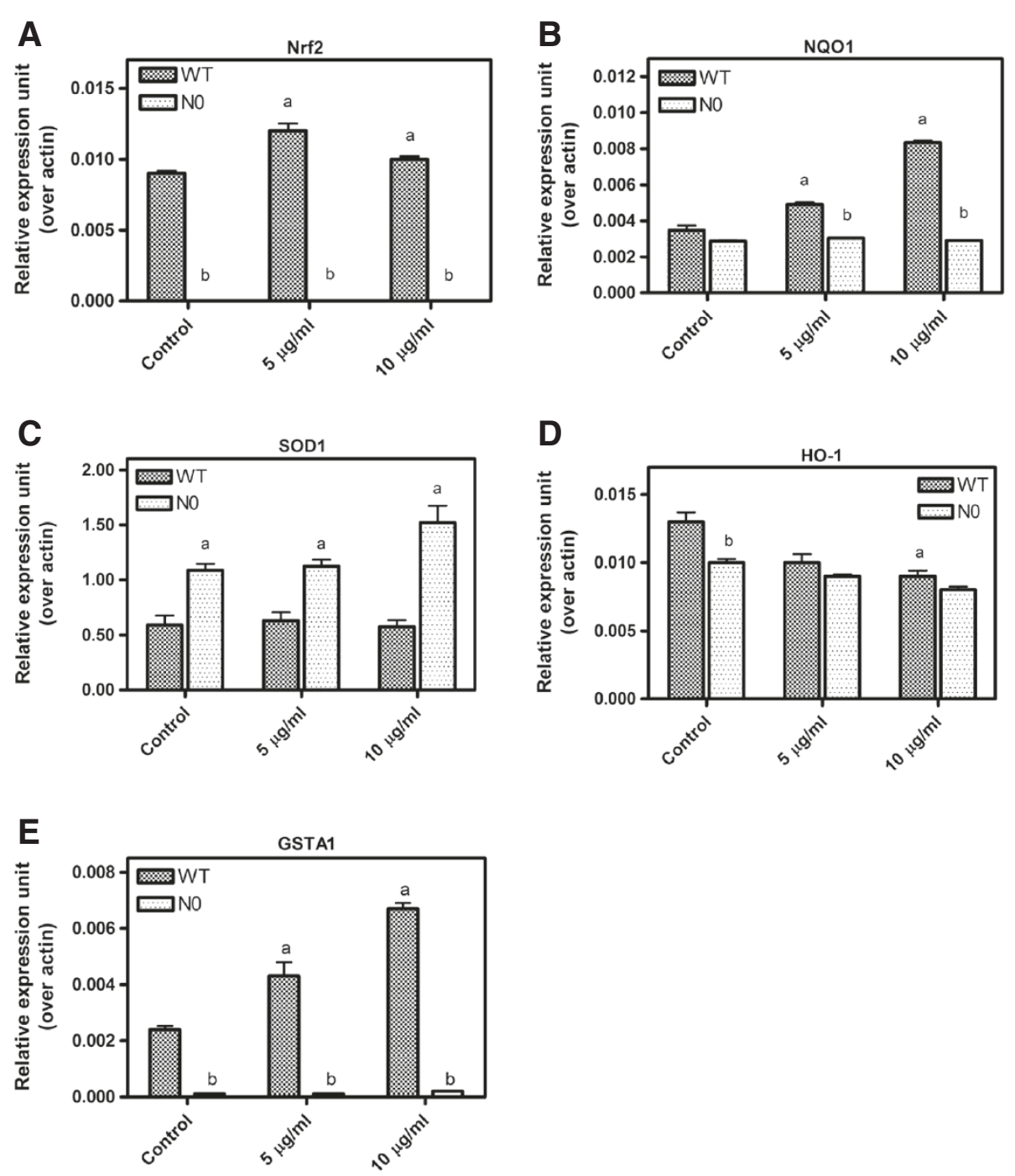

Figure 4 Transcript levels for Nrf2, NQO1 and SOD1 genes following 5 and $10 \mu \mathrm{g} / \mathrm{ml}$ of PB treatment for 24-h. RNAs were isolated and reverse transcribed to CDNA, then amplified by real-time PCR detection system to measure mRNA levels for beta actin, Nrf2 (A), NQO1 (B) and SOD1 (C), HO-1 (D) and GSTA1 (E). Target genes were normalized to beta actin. Data represent \pm S.E.M from three independent experiments. ${ }^{a} P<0.05$, compared to control WT cells; ${ }^{b} P<0.05$, compared to respective WT cells group.

Nrf2 activator, increased luciferase activity 3.5 -fold in rat kidney epithelial NRK cells. Other dietary agents which activate ARE reporter gene with increased expression of Nrf2-targeted genes such as NQO1, HO-1 and GCLC include resveratrol and xanthohumol [36,37]. Other antioxidant, curcumin activated glutathione S-transferase P1 (GSTP1) gene expression by activating the expression of the luciferase gene from a reporter construct carrying GSTP1-ARE [38].

The increased expressions of Nrf2, NQO1 and GSTA1 genes in WT cells but not in N0 cells further validated our claim that PB is a Nrf2/ARE inducer. McWalter et al. [39] reported that transcription factor, Nrf2 was activated by broccoli seeds and isothiocyanates, with induction of
NQO1, GST and GCLC genes and proteins in $\mathrm{Nrf2}^{+/+}$but not in $\mathrm{Nrf}^{-/-}$mice. Our results are supported by the finding of Yoon et al. [40] who found that sulforaphane increased NQO1 and HO-1 proteins in human proximal cells. Cho et al., [8] have shown that Nrf2 gene was upregulated at least 2 -fold higher in $\mathrm{Nrf}^{+/+}$mice than in $\mathrm{Nrf2}^{-/-}$ mice at basal level and also in hyperoxia-induced mice. The possibility of polyphenols in PB such as chavicol or euginol inducing Nrf2 was also reported by a study of Tsai et al., who showed that phenolic compounds from rosemary and carnosic acid induced transcription of Nrf2, ARE luciferase reporter activity and increased expression of NQO1 gene and protein in rat clone 9 cells [41]. Lycopene metabolite, apo-8'-lycopenal that can be 


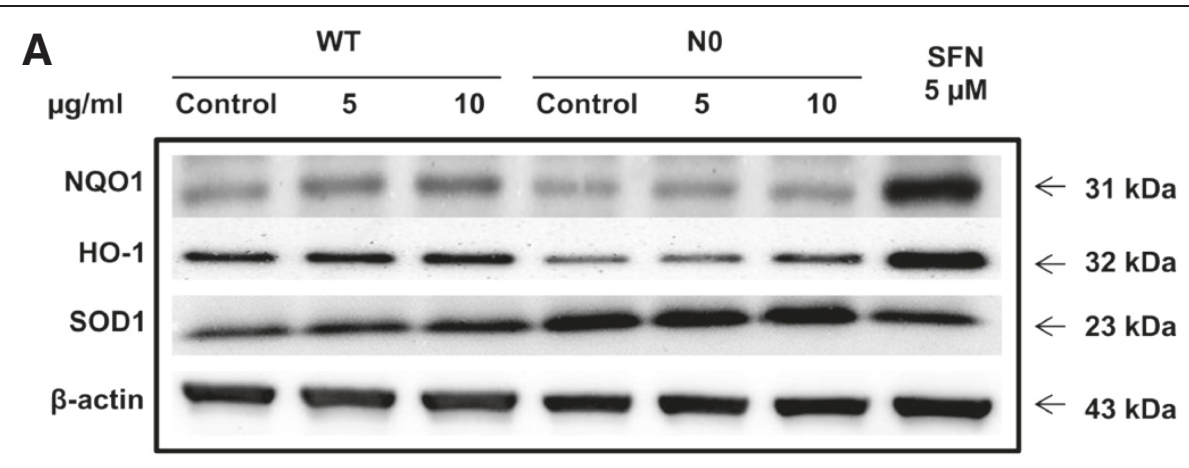

B

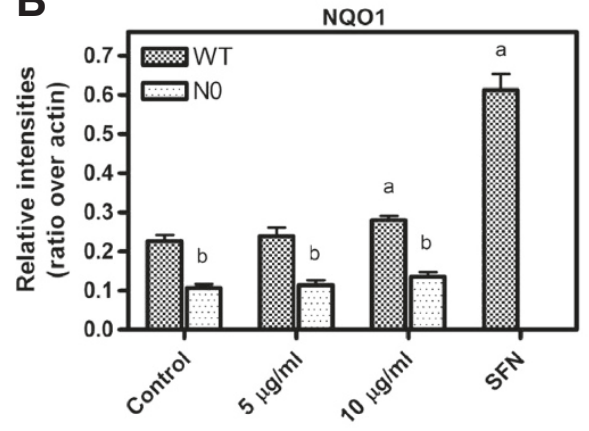

C

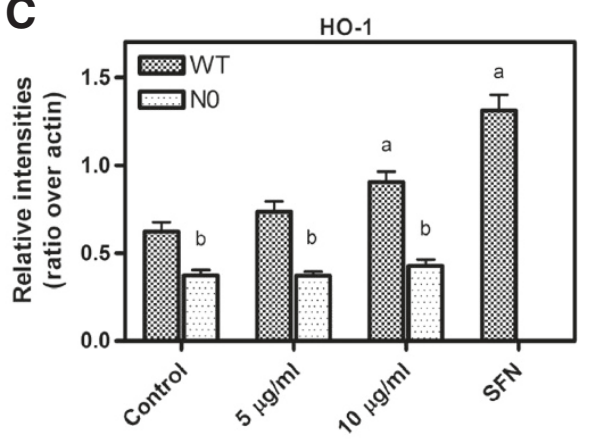

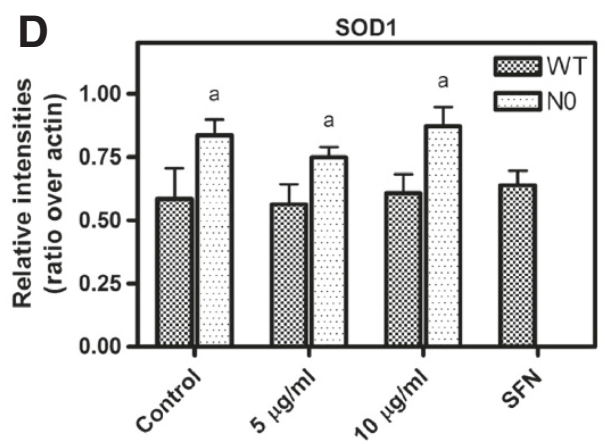

Figure 5 Western blot of NQO1, HO-1 and SOD1 proteins in WT and NO cells treated with PB $(\mathbf{5}$ and $10 \mu \mathrm{g} / \mathrm{ml})$. The blots shown are examples of three separate experiments (A) from $20 \mu \mathrm{g}$ cytosolic proteins and relative intensities over $\beta$-actin for NQO1 (B), HO-1 (C) and SOD1 (D) protein expression after $24 \mathrm{~h}$ treatment of PB. SFN treatment at $5 \mu \mathrm{M}$ was used as positive control. Data represent \pm S.E.M from three independent experiments. ${ }^{a} P<0.05$, compared to control WT cells; ${ }^{b} P<0.05$, compared to respective WT cells group.

found in rat liver and human plasma after consuming lycopene-containing food, induced nuclear translocation, Nrf2-ARE binding activity, HO-1 and NQO1 genes and proteins expression in human hepatoma cell lines, HepG2 [42]. The isothiocyanate, sulforaphane and the flavonoid, epigenin increased gene expression of phase II detoxifying enzyme such as glutathione S-transferase (GSTA1) and UDP-glucuronosyltransferase (UGT1A1) in human colon adenocarcinoma [43]. L-sulforaphane modulates Nrf2-regulated genes including GSH biosynthesis (GCLC), glutathione S-transfreases (GSTA1, GSTA2, GSTA3, GSTM1) and NQO1 in small intestine of $\mathrm{Nrf2}^{+/+}$and $\mathrm{Nrf2}^{-/-}$mice [16].
Our results showed decreased HO-1 mRNA expression after $24 \mathrm{~h}$ treatment with $\mathrm{PB}$ while its protein level was found to be increased. This finding is similar to a timecourse study by Motterlini et al. [44] who showed that HO-1 mRNA expression in bovine aortic endothelial cells reached a maximum after $6 \mathrm{~h}$ treatment with $5 \mu \mathrm{M}$ curcumin and declined after $24 \mathrm{~h}$ treatment.

Contrary to many findings, we noted that SOD1 gene and protein were not expressed in WT but were significantly expressed in N0 cells. Others who found similar results reported that the basal level of some antioxidant enzymes may not be under the influence of Nrf2 gene [45,46]. Kwak et al. [47] found that MnSOD gene was 
1.31 fold higher in Nrf2-disrupted mice compared to wild-type mice at constitutive levels, suggesting that Nrf2 is an essential factor to modulate many, but not all, antioxidant and phase 2 enzymes. The disruption of $\mathrm{Nrf2}$ gene in $\mathrm{Nrf2}^{-/-}$may alter the basal and inducible expression of some genes including SOD1.

\section{Conclusion}

In summary, our findings indicate that PB activated Nrf2/ ARE pathway by dissociating Nrf2 from Keap1, translocating Nrf2 protein into the nucleus, inducing antioxidant response element (ARE), thereby increasing Nrf2-regulated genes (Nrf2, NQO1 and GSTA1) and proteins such as NQO1 and HO-1.

\section{Competing interests}

The authors declare that they have no competing interests.

\section{Authors' contributions}

WNWH performed experiments and analyzed data. WZWN and YAMY designed the study. KMY gave the cells and general supervision. SM helps for data interpretation on gene expression. All authors read and approved the final manuscript.

\section{Acknowledgements}

Our sincere gratitude to Nobunao Wakabayashi and Kwak Mi-Kyoung for providing us with MEFs cells (WT and N0) and plasmid Nqo1 ARE. This research project was funded by Universiti Kebangsaan Malaysia research grant (UKM-GUP-07-21-201) and Mobility Programme (Outbound).

\section{Author details}

'Department of Biochemistry, Faculty of Medicine, Universiti Kebangsaan Malaysia, Jalan Raja Muda Abdul Aziz, 50300 Kuala Lumpur, Malaysia. ${ }^{2}$ College of Pharmacy, The Catholic University of Korea, Bucheon, Gyeonggi-do 420-743, Korea.

Received: 3 February 2013 Accepted: 11 February 2014 Published: 23 February 2014

\section{References}

1. Sharma S, Khan IA, Ali I, Ali F, Kumar M, Kumar A, Johri RK, Abdullah ST, Bani S, Pandey A, Suri KA, Gupta BD, Satti NK, Dutt P, Qazi GN: Evaluation of the antimicrobial, antioxidant, and anti-inflammatory activities of hydroxychavicol for its potential use as an oral care agent. Antimicrob Agents Chemother 2009, 53:216-222.

2. Pin KY, Luqman Chuah A, Abdull Rashih A, Mazura MP, Fadzureena J, Vimala S, Rasadah MA: Antioxidant and anti-inflammatory activities of extracts of betel leaves (Piper betle) from solvents with different polarities. J Trop For Sci 2010, 22:448-455.

3. Aliahmat NA, Mohd Noor MR, Wan Yusof WJ, Makpol S, Wan Ngah WZ, Mohd Yusof YA: Antioxidant enzyme activity and malondialdehyde levels can be modulated by Piper betle, tocotrienol rich fraction and Chlorella vulgaris in aging C57BL/6 mice. Clinics 2012, 67:1447-1454.

4. Saravanan R, Prakasam A, Ramesh B, Pugalendi KV: Influence of Piper betle on hepatic marker enzymes and tissue antioxidant status in ethanol-treated Wistar rats. J Med Food 2002, 5(4):197-204

5. Dasgupta N, De B: Antioxidant activity of Piper betle L. leaf extract in vitro. Food Chem 2004, 88:219-224.

6. Abrahim NN, Kanthimathi MS, Abdul-Aziz A: Piper betle shows antioxidant activities, inhibits MCF-7 cell proliferation and increases activities of catalase and superoxidae dismutase. BMC Complement Altern Med 2012, 12:220.

7. Sies H: Oxidative stress: Oxidants and Antioxidants. Exp Physiol 1997, 82:291-295.

8. Cho JM, Manandhar S, Lee HR, Park HM, Kwak MK: Role of the Nrf2-antioxidant system in cytotoxicity mediated by anticancer cisplatin: Implication to cancer cell resistance. Cancer Lett 2008, 260:96-108.
9. Cho HY, Reddy SP, DeBiase A, Yamamoto M, Kleeberger SR: Gene expression profiling of NRF2-mediated protection against oxidative injury. Free Radic Biol Med 2005, 38:325-343.

10. Dinkova-Kostova AT, Holtzclaw WD, Cole RN, Itoh K, Wakabayashi N, Katoh Y, Yamamoto M, Talalay P: Direct evidence that sulfhydryl groups of Keap1 are the sensors regulating induction of phase 2 enzymes that protect against carcinogens and oxidants. Proc Natl Acad Sci U S A 2002, 99:908-11913.

11. Taguchi K, Motohashi H, Yamamoto M: Molecular mechanisms of the Keap1-Nrf2 pathway in stress response and cancer evolution. Genes Cells 2011, 16:123-140.

12. Rushmore $\mathrm{TH}$, Pickett $\mathrm{CB}$ : Transcriptional regulation of the rat glutathione S-transferase Ya subunit gene: Characterization of xenobiotic-responsive element controlling inducible expression by phenolic antioxidants. J Biol Chem 1990, 265:14648-14653.

13. Nioi $P$, McMohan M, Itoh K, Yamamoto M, Hayes JD: Identification of a novel Nrf2-regulated antioxidant response element (ARE) in mouse NAD $(\mathrm{P}) \mathrm{H}$ :quinine oxidoreductase 1 gene: reassessment of the ARE consensus sequence. Biochem J 2003, 374:337-348.

14. Tong Kl, Padmanabhan B, Kobayashi A, Shang C, Hirotsu Y, Yokoyama S, Yamamoto M: Different electrostatic potential define ETGE and DLG motifs as hinge and latch in oxidative stress response. Mol Cell Biol 2007 27:7511-7521.

15. Itoh K, Wakabayashi N, Katoh Y, Ishii T, Igarashi K, Engel JD, Yamamoto M: Keap1 represses nuclear activation of antioxidant responsive elements by Nrf2 through binding to the amino-terminal Neh2 domain. Genes Dev 1999, 13:76-86.

16. Thimmulappa RK, Mai KH, Srisuma S, Kensler TW, Yamamoto M, Biswal S: Identification of Nrf2-regulated genes induced by the chemopreventive agent sulforaphane by oligonucleotide microarray. Cancer Res 2002, 62:5196-5203.

17. Kwak MK, Wakabayashi N, Itoh K, Motohashi H, Yamamoto M, Kensler TW: Modulation of gene expression by cancer chemopreventive ditiolethiones through the Keap1-Nrf2 pathway: Identification of novel gene clusters for cell survival. J Biol Chem 2003, 278:8135-8145.

18. Hu R, Xu C, Shen G, Jain MR, Khor TO, Gopalkrishnan A, Lin W, Reddy B, Chan JY, Tony Kong AN: Identification of Nrf2-regulated genes induced by chemopreventive isothiocyanate PEITC by oligonucleotide microarray. Life Sci 2006, 79:1944-1955.

19. Nair S, Barve A, Khor TO, Shen GX, Lin W, Chan JY, Cai L, Kong AN: Regulation of Nrf2- and AP1-mediated gene expression by epigallocathechin-3-gallate and sulforaphane in prostate of Nrf2knockout or C57BL/6J mice and PC-3 AP-1 human prostate cancer cells. Acta Pharmacol Sin 2010, 31:1223-1240.

20. Shin D, Park HM, Jung KA, Choi HG, Kim JA, Kim DD, Kim SG, Kang KW, Ku SK, Kensler TW, Kwak MK: The NRF2-heme oxygenase-1 system modulates cyclosporin A-induced epithelial-mesenchymal transition and renal fibrosis. Free Radic Biol Med 2010, 48:1051-1063.

21. Arredondo F, Echeverry C, Abin-Carriquiry JA, Blasina F, Antúnez K, Jones DP, Go YM, Liang YL, Dajas F: After cellular internalization, quercetin causes Nrf2 nuclear translocation, increases glutathione levels, and prevents neuronal death against an oxidative insult. Free Radic Biol Med 2010, 49:738-747.

22. Kwak MK, Wakabayashi N, Greenlaw JL, Yamamoto M, Kensler TW: Antioxidants enhance mammalian proteasome expression through the Keap1-Nrf2 signaling pathway. Mol Cel Biol 2003, 23:8786-8794.

23. Kwak M-K, Itoh K, Yamamoto M, Kensler TW: Enhanced expression of the transcription factor Nrf2 by cancer chemopreventive agents: Role of antioxidant response element-like sequences in the Nrf2 promoter. Mol Cell Biol 2002, 22(9):2883-2892.

24. Chang MC, Uang BJ, Wu HL, Lee JJ, Hahn LJ, Jeng JH: Inducing the cell cycle arrest and apoptosis of oral KB carcinoma cells by hydroxychavicol: roles of glutathione and reactive oxygen species. Br J Pharmacol 2002, 135:619-630.

25. Higgins LG, Kelleher MO, Eggleston IM, Yamamoto M, Hayes JD: Transcription factor Nrf2 mediates an adaptive response to sulforaphane that protects fibroblasts in vitro against the cytoxic effects of electrophiles, peroxides and redox-cycling agents. Toxicol Appl Pharmacol 2009, 237:267-280.

26. Wakabayashi N, Dinkova-Kostova, Holtzclaw WD, Kang M-I, Kobayashi A, Yamamoto M, Kensler TW, Talalay P: Protection against electrophile and oxidant stress by induction of the phase 2 response: Fate of cysteines of the Keap1 sensor modified by inducers. PNAS 2004, 101:2040-2045. 
27. Liu XP, Goldring CEP, Copple IM, Wang HY, Wei W, Kitteringham NR, Park BK: Extract of Ginkgo biloba induces phase 2 genes through Keap1-Nrf2-ARE signaling pathway. Life Sci 2007, 80:1586-1591.

28. Boettler U, Sommerfeld Volz N, Pahlke G, Teller N, Somoza V, Lang R, Hofmann T, Marko D: Coffee constituents as modulator of Nrf2 nuclear translocation and ARE (EpRE)-dependent gene expression. J Nutr Biochem 2011, 22:426-440.

29. Wagner AE, Ernst I, lori R, Desel C, Rimbach G: Sulforaphane but not ascorbigen, indole-3-carbinole and ascorbic acid activates the transcription factor Nrf2 and induces phase-2 and antioxidant enzymes in human keratinocytes in culture. Exp Dermatol 2009, 19:137-144.

30. Rushmore $\mathrm{TH}$, King RG, Paulson KE, Pickett CB: Regulation of glutathione S-transferase Ya subunit gene expression: identification of a unique xenobiotic-responsive element controlling inducible expression by planar aromatic compounds. Proc Natl Acad Sci U S A 1990, 87:3826-3830.

31. Wasserman WW, Fahl WE: Functional antioxidant responsive elements. Proc Natl Acad Sci U S A 1997, 94:5361-5366.

32. Prestera T, Talalay P, Alam J, Ahn YI, Lee PJ, Choi AM: Parallel induction of heme oxygenase- 1 and chemoprotective phase 2 enzymes by electrophiles and antioxidants: regulation by upstream antioxidant-responsive elements (ARE). Mol Med 1995, 1:827-837.

33. Favreau LV, Pickett CB: Transcriptional regulation of the rat $N A D(P) H$ : quinone reductase gene: identification of regulatory elements controlling basal level expression and inducible expression by planar aromatic compounds and phenolic antioxidants. J Biol Chem 1991, 266:4556-4561.

34. Wild AC, Gipp JJ, Mulcahy RT: Overlapping antioxidant response element and PMA response element sequences mediate basal and bnaphthoflavone-induced expression of the human c-glutamylcysteine synthetase catalytic subunit gene. Biochem J 1998, 332:373-381.

35. Ikeda H, Serria MS, Kakizaki I, Hatayama I, Satoh K, Tsuchida S, Muramatsu M, Nishi S, Sakai M: Activation of mouse Pi-class glutathione S-transferase gene by Nrf2 (NF-E2-related factor 2) and androgen. Biochem J 2002, 364:563-570.

36. Ungvari Z, Bagi Z, Feher A, Recchia FA, Sonntag WE, Pearson K, Cabo R, Csiszar A: Resveratrol confers endothelial protection via activation of the antioxidant transcription factor Nrf2. Am J Physiol Heart Circ Physiol 2010, 299: $\mathrm{H} 18-\mathrm{H} 24$.

37. Lee IS, Lim J, Gal J, Kang JC, Kim HJ, Kang BY, Choi HJ: Anti-inflammatory activity of xanthohumol involves heme oxygenase-1 induction via NRF2ARE signalling in mikroglial BV2 cells. Neurochem Int 2011, 58:153-160.

38. Nishinaka T, Ichijo Y, Ito M, Kimura M, Katsuyama M, Iwata K, Miura T, Terada T, Yabe-Nishimura C: Curcumin activates human glutathione S-transferase P1 expression through antioxidant response element. Toxicol Lett 2007 170:238-247.

39. McWalter GK, Higgins LG, McLellan LI, Henderson CJ, Song L, Thornalley PJ, Itoh K, Yamamoto M, Hayes JD: Transcription factor Nrf2 is essential for induction of $\mathrm{NAD}(\mathrm{P}) \mathrm{H}$ : quinone oxidoreductase 1, glutathione S-transferases and glutamate cysteine ligase by broccoli seeds and isothiocyanates. J Nutr 2004, 134:3499S-3506S.

40. Yoon HY, Kang NI, Lee HK, Jang KY, Park JW, Park BH: Sulforaphane protects kidneys against ischemia-reperfusion injury through induction of the Nrf2-dependent phase 2 enzyme. Biochem Pharmacol 2008, 75:2214-2223.

41. Tsai CW, Lin CY, Wang YJ: Carnosic acid induces the NAD(P)H: quinone oxidoreductase 1 expression in rat clone 9 cells through p38/Nuclear factor Erythroid-2 relted factor 2 pathway. J Nutr 2011, 141:2119-2125.

42. Yang C-M, Huang S-M, Liu C-L, Hu M-L: Apo-8'-lycopenal Induces Expression of HO-1 and NQO-1 via the ERK/p38-Nrf2-ARE Pathway in Human HepG2 Cells. J Agric Food Chem 2012, 60:1576-1585.

43. Svehlikova V, Wang S, Jakubikova J, Williamson G, Mithen R, Bao Y: Interactions between sulforaphane and apigenin in the induction of UGT1A1 and GSTA1 in CaCo-2 cells. Carcinogenesis 2004, 25(9):1629-1637.

44. Motterlini R, Foresti R, Bassi R, Green CJ: Curcumin, an antioxidant and anti-inflammatory agent, induces heme oxygenase- 1 and protects endothelial cells against oxidative stress. Free Radic Biol Med 2000, 28(8):1303-1312.

45. Reisman SA, Yeager RL, Yamamoto M, Klaassen CD: Increased Nrf2 activation in livers from Keap1-knockdown mice increases expression of cytoprotective genes that detoxify electrophiles more than those that detoxify reactive oxygen species. Toxicol Sci 2009, 108:35-47.
46. Zhu H, Itoh K, Yamamoto M, Zweier JL, Li Y: Role of Nrf2 signaling in regulation of antioxidants and phase 2 enzymes in cardiac fibroblasts: Protection against reactive oxygen species and nitrogen species-induced cell injury. FEBS Lett 2005, 579:3029-3036.

47. Kwak MK, Itoh K, Yamamoto M, Sutter TR, Kensler TW: Role of transcription factor Nrf2 in the induction of hepatic phase 2 and antioxidative enzymes in vivo by the cancer chemopreventive agent, 3H-1,2-dithiole3-thione. Mol Med 2001, 7:135-145.

doi:10.1186/1472-6882-14-72

Cite this article as: Wan Hasan et al.: Piper betle induces phase I \& II genes through Nrf2/ARE signaling pathway in mouse embryonic fibroblasts derived from wild type and Nrf2 knockout cells. BMC Complementary and Alternative Medicine 2014 14:72.

\section{Submit your next manuscript to BioMed Central and take full advantage of:}

- Convenient online submission

- Thorough peer review

- No space constraints or color figure charges

- Immediate publication on acceptance

- Inclusion in PubMed, CAS, Scopus and Google Scholar

- Research which is freely available for redistribution 